\title{
Biophysical characterization of the interaction between M2-1 protein of hRSV and quercetin
}

\author{
Thiago Salem Pançonato Teixeira ${ }^{\mathrm{a}, \mathrm{c}}$, Ícaro Putinhon Caruso ${ }^{\mathrm{b}, \mathrm{c}}$, \\ Bruno Rafael Pereira Lopes ${ }^{\mathrm{e}}$, Luis Octávio Regasini ${ }^{\mathrm{d}}$, Karina Alves de Toledo ${ }^{\mathrm{e}}$, \\ Marcelo Andrés Fossey ${ }^{\mathrm{b}, \mathrm{c}}$, Fátima Pereira de Souza ${ }^{\mathrm{b}, \mathrm{c}, *}$ \\ a Instituto de Biociências, Letras e Ciências Exatas, UNESP Univ Estadual Paulista, Campus São José do Rio Preto, Departamento de Biologia, Brazil \\ ${ }^{\mathrm{b}}$ Instituto de Biociências, Letras e Ciências Exatas, UNESP Univ Estadual Paulista, Campus São José do Rio Preto, Departamento de Física, Brazil \\ ' Instituto de Biociências, Letras e Ciências Exatas, UNESP Univ Estadual Paulista, Campus São José do Rio Preto, Centro Multiusuário de Inovação \\ Biomolecular, Laboratório de Biologia Molecular, Brazil \\ d Instituto de Biociências, Letras e Ciências Exatas, UNESP Univ Estadual Paulista, Campus São José do Rio Preto, Departamento de Química e Ciências \\ Ambientais, Brazil \\ e Faculdade de Ciências e Letras, UNESP Univ Estadual Paulista, Campus Assis, Departamento de Ciências Biológicas, Laboratório de Imunologia Celular e \\ Molecular, Brazil
}

\section{A R T I C L E I N F O}

\section{Article history:}

Received 27 May 2016

Received in revised form 18 July 2016

Accepted 9 November 2016

Available online 13 November 2016

\section{Keywords:}

hRSV

M2-1

Quercetin

Biophysical analyses

Molecular docking

\begin{abstract}
A B S T R A C T
hRSV is the major causative agent of acute respiratory infections. Among its eleven proteins, M2-1 is a transcription antiterminator, making it an interesting target for antivirals. Quercetin is a flavonol which inhibits some virus infectivity and replication. In the present work, the M2-1 gene was cloned, expressed and the protein was purified. Thermal stability and secondary structure were analyzed by circular dichroism and the interaction with Quercetin was evaluated by fluorescence spectroscopy. Molecular docking experiments were performed to understand this mechanism of interaction. The purified protein is mainly composed of $\alpha$-helix, with a melting temperature of $328.6 \mathrm{~K}\left(\approx 55^{\circ} \mathrm{C}\right)$. M2-1 titration with Quercetin showed it interacts with two sites, one with a strong constant association $\mathrm{K} 1$ ( site $1 \approx 1.5 \times 10^{6} \mathrm{M}^{-1}$ ) by electrostatic interactions, and another with a weak constant association $\mathrm{K} 2$ (site $2 \approx 1.1 \times 10^{5} \mathrm{M}^{-1}$ ) by a hydrophobic interaction. Ligand's docking shows it interacts with the N-terminus face in a more polar pocket and, between the domains of oligomerization and RNA and P protein interaction, in a more hydrophobic pocket, as predicted by experimental data. Therefore, we postulated this ligand could be interacting with important domains of the protein, avoiding viral replication and budding.
\end{abstract}

(C) 2016 Elsevier B.V. All rights reserved.

\section{Introduction}

The leading viral agent responsible for acute lower respiratory infection (ALRI) in infants and children are the Human Respiratory Syncytial Virus (hRSV) [1,2]. Each year, hRSV is responsible for over 30 million ALRI cases with a result of $60,000-190,000$ deaths of children under five years old, elderly and immunocompromised people [3]. It is estimated that $70 \%$ of infants under one year old are

\footnotetext{
* Corresponding author at: Correspponding author at: Rua Cristóvão Colombo, 2265, Jardim Nazareth, São José do Rio Preto - SP, 15054-000, Brazil. E-mail addresses: thiago_spt@yahoo.com.br (T.S.P. Teixeira), ykrocaruso@hotmail.com (Í.P. Caruso), brunorpl@hotmail.com (B.R.P. Lopes), luisregasini@gmail.com (L.O. Regasini), karinafcla@gmail.com (K.A.d. Toledo), mafossey@gmail.com (M.A. Fossey), fatyssouza@gmail.com, fatyssouza@yahoo.com.br (F.P.d. Souza).
}

infected with hRSV and $100 \%$ of two-year-old children have been infected at least once [4,5].

RSV is classified in the order Mononegavirales, family Paramyxoviridae, subfamily Paramyxovirinae, genus Pneumovirus. They are enveloped viruses with a helical capsid [6] and their genome is composed of a non-segmented single-stranded RNA with negative polarity, of about $15 \mathrm{~kb}$ encompassing 10 genes in the following order: 3'-NS1-NS2-N-P-M-SH-G-F-M2-L-5'. Still, eleven proteins are translated due to an open reading frame at matrix-2 protein (M2), forming M2-1 and M2-2.

Four of these eleven proteins (N, P, L and M2-1) form the complex RNA-dependent RNA polymerase (RdRp), which is involved in genome replication and transcription. M2-1 protein is important for the transcription all mRNAs, as it is a factor that prevents premature transcription stop [7]. Moreover, during viral capsule formation, the N-terminus portion of M protein associates with M2- 
1 protein [8,9], as well as with $\mathrm{N}$ and $\mathrm{P}$ proteins [10] to interrupt viral transcription and direct virus assembly and budding.

Structurally, M2-1 protein is a tetramer [11] composed mainly of alpha helix [12,13], with four distinct regions: the first 32 residues in the $\mathrm{N}$-terminus bind to zinc (zinc finger) and contribute to transcription (are mandatory for its function, but the correct mechanism of action is still unknown) [14-16]; the oligomerization domain, situated between His33 and Gly62; a globular domain composed mainly of alpha helix (Ala63-Ser170) capable of binding to $\mathrm{P}$ protein and RNA; and a C-terminus region with low organization degree [13].

The treatment for RSV infections is mainly symptomatic, including oxygen support and hydration. Nevertheless, the mortality is high, with an annual cost to the health system $[17,18]$. Despite the long term research with hRSV, there is no effective drug or available vaccine in the market yet. There are only a few drugs which lack specificity and are expensive, such as ribavirin [19-24].

Natural products are a relevant source of antiviral agents $[25,26]$. Flavonoid is a group of phenolic compounds that are widely diverse among natural products which have important properties as antitumor, antioxidant, antiviral and anti-inflammatory $[27,28]$. Quercetin $\left(3,3^{\prime}, 4^{\prime}, 5,7\right.$-pentahydroxyflavone) is an excellent free radical scavenger, metal chelator and is one of the most potent bioflavonoids studied, which possesses a variety of pharmacological properties, including anti-inflammatory, antineoplastic, cardio protective and anticancer activities [29,30]. Its anticancer effect is believed to result from its protective anti-oxidant action [31-34] Most importantly, quercetin has shown anti-viral activity. It was effective in inhibiting HBsAg and HBeAg secretion in HBVinfected cells [35], as well as HCV replication [36], HIV-1 reverse transcriptase [37], and transcriptase from avian myeloblastosis, Rous-associated virus-2 and Maloney murine leukemia virus [38].

Ahmed-Belkacem and co-workers (2014) [39] reported that flavonoids, especially quercetin, were able to inhibit approximately $80 \%$ of HCV RdRp activity. This effect was due to flavonol binding to the entrance of the RNA template tunnel. In 1985, Kaul et al. [40], observed that quercetin was able to inhibit RSV infection and replication. Therefore, quercetin can probably bind to some RdRp proteins of RSV and prevent replication or transcription.

As M2-1 is a target protein for viral replication, transcription and budding of hRSV, and because of the promising properties of quercetin, in this work we investigated the interaction of both molecules by fluorescence spectroscopy and by bioinformatics tools.

\section{Material and methods}

\subsection{Expression, purification and identification of M2-1 protein}

An M2-1 cDNA from the Human Respiratory Syncytial Virus (hRSV) strain A2 was inserted into pGEX4T-1vector (GE healthcare), allowing the expression of full-length M2-1 which was $\mathrm{N}$-terminally fused to a GST affinity tag and a thrombin protease recognition sequence. The resulting plasmid was transformed in cultures of Escherichia coli BL21 Gold (DE3) (Agilent Technologies), which were grown until they reachedOD $6000.6-0.8$ at $37^{\circ} \mathrm{C}$ and protein production was induced with $400 \mu \mathrm{M}$ isopropyl $\beta$-D1-thiogalactopyranoside (IPTG), with $50 \mu \mathrm{M}$ zinc sulfate $\left(\mathrm{ZnSO}_{4}\right)$ to aid in the correct folding of the zinc finger, for $16 \mathrm{~h}$ at $28^{\circ} \mathrm{C}$. Cells were recovered by centrifugation and suspended in $5 \mathrm{~mL}$ lysis buffer [ $50 \mathrm{mM}$ Tris- $\mathrm{Cl} \mathrm{pH} 7.5,1 \mathrm{M} \mathrm{NaCl}, 1 \mathrm{x}$ complete protease inhibitor mixture EDTA-free (Sigma Aldrich), $1 \mathrm{mM}$ $\beta$-mercaptoethanol, $1 \mathrm{mM} \mathrm{CaCl}_{2}, 10 \mathrm{mM} \mathrm{MgSO}_{4}$ ] per $100 \mathrm{~mL}$ of pelleted culture. Cells were incubated on ice for $30 \mathrm{~min}$ and lysis was completed by sonication ( 15 cycles $-15 \mathrm{~s}$ on and $45 \mathrm{~s}$ off - potency of $36 \mathrm{~W}$ ). The clarified supernatant containing the soluble GST-M21 protein was applied in batch to glutathione Sepharose $4 \mathrm{~B}$ resin (GE Healthcare) at $4^{\circ} \mathrm{C}$ for $4 \mathrm{~h}$ with rotation. The resin was pelleted and washed with 4 volumes of lysis buffer and 5 volumes of PBS buffer. M2-1 was cleaved from GST in the resin overnight at $16^{\circ} \mathrm{C}$ by using thrombin protease which was expressed and purified in-house. Cleaved M2-1 protein was eluted by pelleting the resin and collecting the supernatant, which was applied on a $30 \mathrm{~mL}$ Sepharose 20/300 size exclusion chromatography (SEC) column (GE Healthcare) equilibrated with PBS buffer. The identity of the purified protein was confirmed by accurate mass determination using denaturing mass spectrometry. The protein was confirmed to be RNA-free by spectrophotometry (OD 260/280 with a ratio of 0.27). Protein concentration was determined spectrophotometrically using a molar extinction coefficient $\left(\varepsilon_{280}\right)$ of $13200 \mathrm{M}^{-1} \mathrm{~cm}^{-1}$, calculated using the Expasy ProtParam tool and in agreement with a previous report [13].

\subsection{Primary protein structure sequencing}

The primary sequence of M2-1 protein was determined in order to see if it was correctly expressed. The protein sequence was determined by the ShotGun method [41] by the group of Prof. Dr. Mario Sérgio Palma at Centro de Estudos de Insetos Sociais - UNESP.

\subsection{Sample preparation}

Stock solution of quercetin $(\mathrm{MM}=338.3 \mathrm{Da})$ was prepared in $10 \%$ ultra-pure water and $90 \%$ ethanol, and M2-1 protein was prepared in a solution of $\mathrm{PBS} \mathrm{pH}=7.4$. To determine Quercetin stock solution concentration, a molar extinction coefficient of $\epsilon_{375}=21.880 \mathrm{M}^{-1} \mathrm{~cm}^{-1}$ at $376 \mathrm{~nm}$ was employed [43] and to determine M2-1 concentration, the molar extinction coefficient used was of $\epsilon_{280}=13.200 \mathrm{~cm}^{-1} \mathrm{M}^{-1}$ at $280 \mathrm{~nm}$ [44].

\subsection{Circular dichroism (CD) spectroscopy}

GST-free M2-1 was analyzed using a Jasco J-810 spectropolarimeter at $25^{\circ} \mathrm{C}$ equipped with $1-\mathrm{cm}$ thick quartz cells. Protein samples were loaded into the cuvettes, and spectra between 200 and $260 \mathrm{~nm}$ were recorded using a velocity of $20 \mathrm{~nm} / \mathrm{min}$, with a $2 \mathrm{~s}$ answer and bandwidth of $1.0 \mathrm{~nm}$, totalizing 10 accumulations. The baseline was corrected subtracting buffer spectrum from protein spectrum. The far-UV CD experiments of the protein were expressed as milli degrees and performed in triplicate. The fraction of secondary structure was calculated using CDPro program [42]. From these data, it was possible to check the integrity of the target protein.

\subsection{Thermal denaturation}

The thermal denaturation of M2-1 protein was carried out on a spectropolarimeter Jasco-815 equipped with a Peltier temperature control and quartz cuvette of $5 \mathrm{~mm}$. The measurements were performed in the temperature range from $20^{\circ} \mathrm{C}$ to $80^{\circ} \mathrm{C}$, with heating velocity of $1{ }^{\circ} \mathrm{C} / \mathrm{min}$ and readings at each $5^{\circ} \mathrm{C}$. The wavelength was measurement at $222 \mathrm{~nm}$ with a 2-s answer and bandwidth of $1.0 \mathrm{~nm}$, totalizing three accumulations.

\subsection{Fluorescence spectroscopy}

Fluorescence quenching was performed using the Cary Eclipse Fluorescence Spectrophotometer with Single Cell Peltier temperature control. For protein titration with Quercetin, protein concentration was initially determined, so that a proportion of ligand:protein of 0.1 to 4.5 would be used. Titration was performed 
three times using a temperature control. A $1 \mathrm{~cm}$ quartz cuvette was used, with emission and excitation bandwidths of $5 \mathrm{~nm}$. The excitation wavelength was of $280 \mathrm{~nm}$ and the emission was recorded between 295 and $500 \mathrm{~nm}$, totalizing five accumulations.

For fluorescence quenching data analysis, it is admitted that the protein-ligand complex formation totally suppresses M2-1 fluorescence, i.e., after each addition of Quercetin, the reminiscent fluorescence corresponds to the protein that has not interacted with ligand (nonfluorescent ground-state complex). Thus, it is possible to calculate the fraction of the protein complexed with the ligand $\left(f_{b}\right)$ throughout the fluorescence variation with the ligand increase:

$\mathrm{f}_{\mathrm{b}}=\frac{\mathrm{F}_{0}-\mathrm{F}}{\mathrm{F}_{0}}=\frac{[\mathrm{PL}]}{\left[\mathrm{P}_{\mathrm{T}}\right]}$,

where $F_{0}$ is $\mathrm{M} 2-1$ protein fluorescence in the absence of the ligand, $F$ is the fluorescence after ligand addition, $[P L]$ is the concentration of the protein complexed with $n$ ligands and $\left[P_{T}\right]$ is the total protein concentration. Therefore, there is a relation between the fraction of the bound ligand and the fraction of the protein complexed with the ligand $\left(f_{b}\right)$ :

$\vartheta=\frac{\left[L_{b}\right]}{\left[P_{T}\right]}=n f_{b}$

where $\left[L_{b}\right]$ is the concentration of ligand bound to the protein and $n$ is number of ligands bound to each protein.

From the values calculated for the bound ligand fraction, it is possible to obtain the Scatchard plot for the interaction between M2-1 and Quercetin. The multiphasic Scatchard plot was analyzed by using a linear combination of simpler plots. For each linear region of Scatchard plot the following parameters were determined: the total number of binding sites equals the intercept on the abscissa, and the association constant equals the slope.

\subsection{Thermodynamic analysis}

From the association constant values for M2-1/Quercetin complex determined by using fluorescence quenching experiments at different temperatures $(298,304$, and $310 \mathrm{~K})$, van't Hoff analysis was performed to obtain the enthalpy change $(\Delta \mathrm{H})$ of interaction. From the declivity of the van't Hoff plot $(-R \ln (\mathrm{K})$ vs $1 / \mathrm{T}) \Delta \mathrm{H}$ value is calculated using $R=1.98 \mathrm{calmol}^{-1} . \mathrm{K}^{-1}$.

The Gibbs free energy change $(\Delta \mathrm{G})$ and entropy change $(\Delta S)$ were calculated using the following equation:

$\Delta G=-R T \ln (K)=\Delta H-T \Delta S$

\subsection{Molecular docking}

All molecular docking calculations were performed with an AutoDock 4.0 [45]. The GRID was built centralized in the protein with a box width of $100 \times 100 \times 100$ and spacing points of $0.5 \AA$. The Lamarckian Genetic Algorithm (LGA) search was used with the Genetic Algorithm (GA) number of 200 steps, population size of 150 and medium search of maximum evaluation number. The remaining parameters were kept as default. The results were analyzed using MGL AutoDockTools [46] and the pictures were made with the Chimera program [47] and Maestro 2015-4 [48].

\section{Results and discussion}

The M2-1 gene was cloned in a 603 bp length (Fig. S1), inserted in pGEX4T-1 vector and transformed in strain BL21 Gold (DE3). Five clones were selected to express the protein (Fig. S2), all of which expressed M2-1 protein fused to GST ( $\sim 48.47 \mathrm{kDa})$. To confirm the correct sequence of the protein which was expressed and purified

\begin{tabular}{|c|}
\hline MSPILGYWKIKGLVQPTRLLLEYLEEKYE \\
\hline RDEGDKWRNKKFELGLEFPNLPYYIDGDVKLTQS \\
\hline MAIIRYIADKHNMLGGCPKERAEISMLEGAVLDI \\
\hline RYGVSRIAYSKDEETLKVDFLSKLPEMLKMF'EDR \\
\hline LCHKTYLNGDHVTHPDFMLYDALDVVLYMDPMCL \\
\hline DAFPKLVCFKKRIEAIPQIDKYLKSSKYIAWPLQ \\
\hline GWQATFGGGDHPPKSDIVPRGSMSRRNPCKEEIR \\
\hline GHCLNGKRCHFSHNYFEWPPHALLVRQNFMLNRI \\
\hline LKSMDKS IDTLSEISGAAELDRTEEYALGVVGVL \\
\hline ESYIGSINNITKQSACVAMSKLLTELNSDDIKKL \\
\hline RDNEELNSPKIRVYNTVISYIESNRKNNKQTIHL \\
\hline$\underline{L}$ RLPADVLKKTIKNTLDIHKS ITINNPKELTVS \\
\hline DTNDHAKNNDTT \\
\hline
\end{tabular}

Fig. 1. M2-1 protein sequenced by the ShotGun method. In bold is the GST sequence in italics is M2-1 sequence, in bold, italics and underlined is the thrombin cleaving site and underlined is the amino acid sequence found by the ShotGun Method.

(Fig. S3), it was sequenced by the ShotGun method. The primary sequence (Fig. 1) was aligned using BLASTp Tool, resulting in a $67 \%$ coverage and $46 \%$ identity to hRSV M2-1 protein (access code AAX23995).

Once the protein was obtained, it was necessary to observe if it maintained its structure at the temperatures employed in the fluorescence experiments. The results of circular dichroism presented characteristics of a structured protein, showing a minimum ellipticity at 209 and $222 \mathrm{~nm}$. The secondary structure analysis indicates that the protein has approximately $40 \%$ of alpha helix, $10 \%$ of beta sheet, $19 \%$ of turns and $31 \%$ of random coils (50\% turns and random coils) (Fig. 2). Our results are in accordance with those described by Tran and colleagues [13], which showed that M2-1 protein is composed of $38 \%$ alpha helix, $12 \%$ beta sheet, $10 \%$ turns and $40 \%$ random coils.

The melting temperature obtained was $\mathrm{Tm}=328.6 \mathrm{~K} \approx 55^{\circ} \mathrm{C}$, indicating that M2-1 is thermally stable considering the temperature range of many physiologic processes $\left(37^{\circ} \mathrm{C}=310 \mathrm{~K}\right)$. Thermal denaturation curve analysis (Fig. 3) revealed that in the experimental conditions, there was approximately $10 \%$ denaturation in the biologic temperature range (approximately $37^{\circ} \mathrm{C}$ ), not interfering in the isothermal titration experiments performed to identify the interaction profile between M2-1 protein and Quercetin.

The fluorescence quenching spectra of M2-1 with Quercetin at $298 \mathrm{~K}\left(25^{\circ} \mathrm{C}\right)$ are shown in Fig. 4 . It is possible to observe that M2-1 fluorescence intensity decreases with the rise in Quercetin concentration, suggesting this flavonoid affects the microenvironment of fluorophores (tyrosine and tryptophan) of the protein.

From the fluorescence quenching data analysis using Scatchard plot, it was possible to obtain the association constant and the number of ligand binds per protein for the establishment of M2$1 /$ Quercetin complex. The result of this analysis (Fig. 5) shows there are two binding sites which are independent from each other, one with a strong binding association $\left(\sim 1.5 \times 10^{6} \mathrm{M}^{-1}\right)$ occupied by 0.25 ligand and another site with a weak binding association $\left(\sim 1.1 \times 10^{5} \mathrm{M}^{-1}\right)$, occupied by one ligand. Literature describes that M2-1 protein forms a tetramer; therefore, this result suggests the existence of one strong binding site formed by the four tetramer units, which is occupied by one ligand $(0.25$ ligand/protein $=1$ ligand/tetramer), the second binding site being occupied by one ligand ( 1 ligand/protein $=4$ ligands/tetramer). 


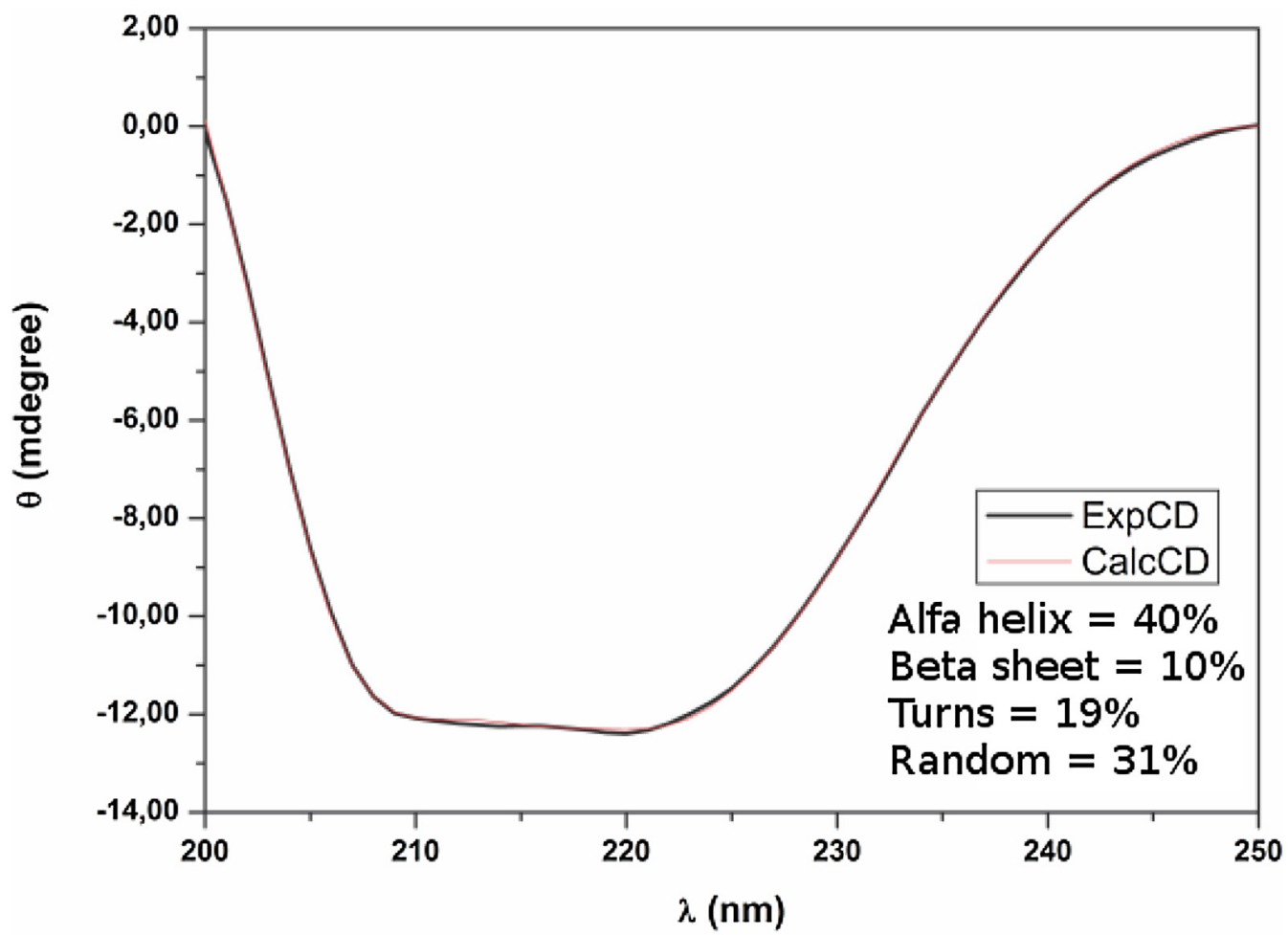

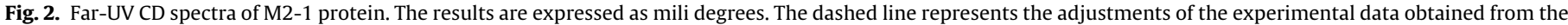
deconvolution of the $\mathrm{CD}$ spectrum.

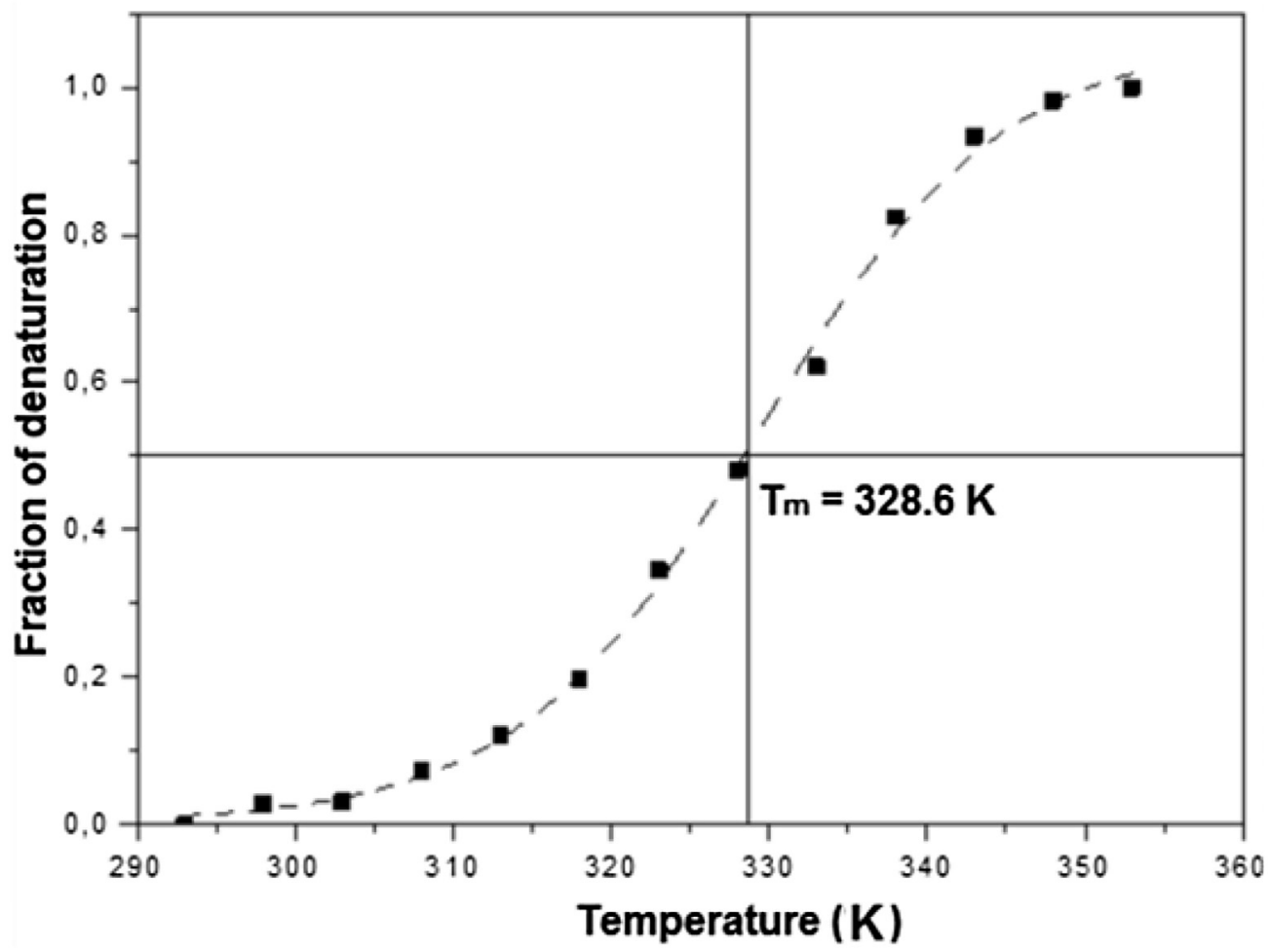

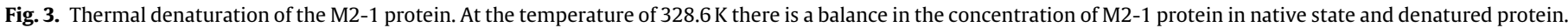
The dashed line is a nonlinear adjustment of the measure point.

Aiming at identifying the type of interaction between M2-1 protein and Quercetin in the two binding sites, titration experiments were performed at three different temperatures, $298 \mathrm{~K}, 304 \mathrm{~K}$ and $310 \mathrm{~K}$. The values for the two association constants K1 (strong site) and K2 (weak site) obtained at three different temperatures are shown in Table 1.

In Fig. 6, van't Hoff plot is shown for the two association constants of the M2-1/Quercetin complex. It is possible to verify from 


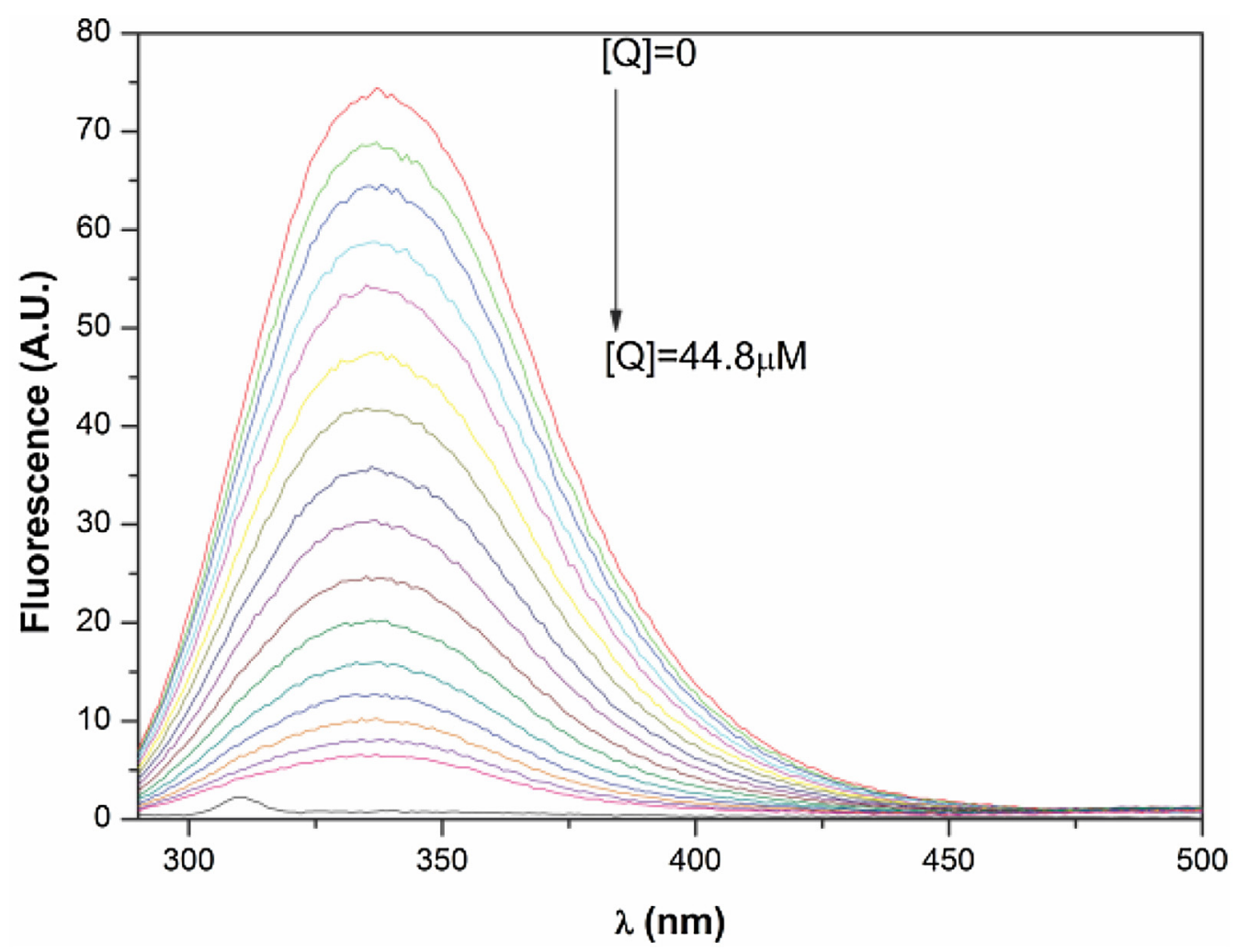

Fig. 4. Fluorescence quenching spectra of M2-1 protein with Quercetin at $25^{\circ} \mathrm{C}$. The M2-1 protein was in a concentration of $10 \mu \mathrm{M}$ and the concentration of Quercetin ([Q]) varied from 0 to $44.8 \mu \mathrm{M}$.

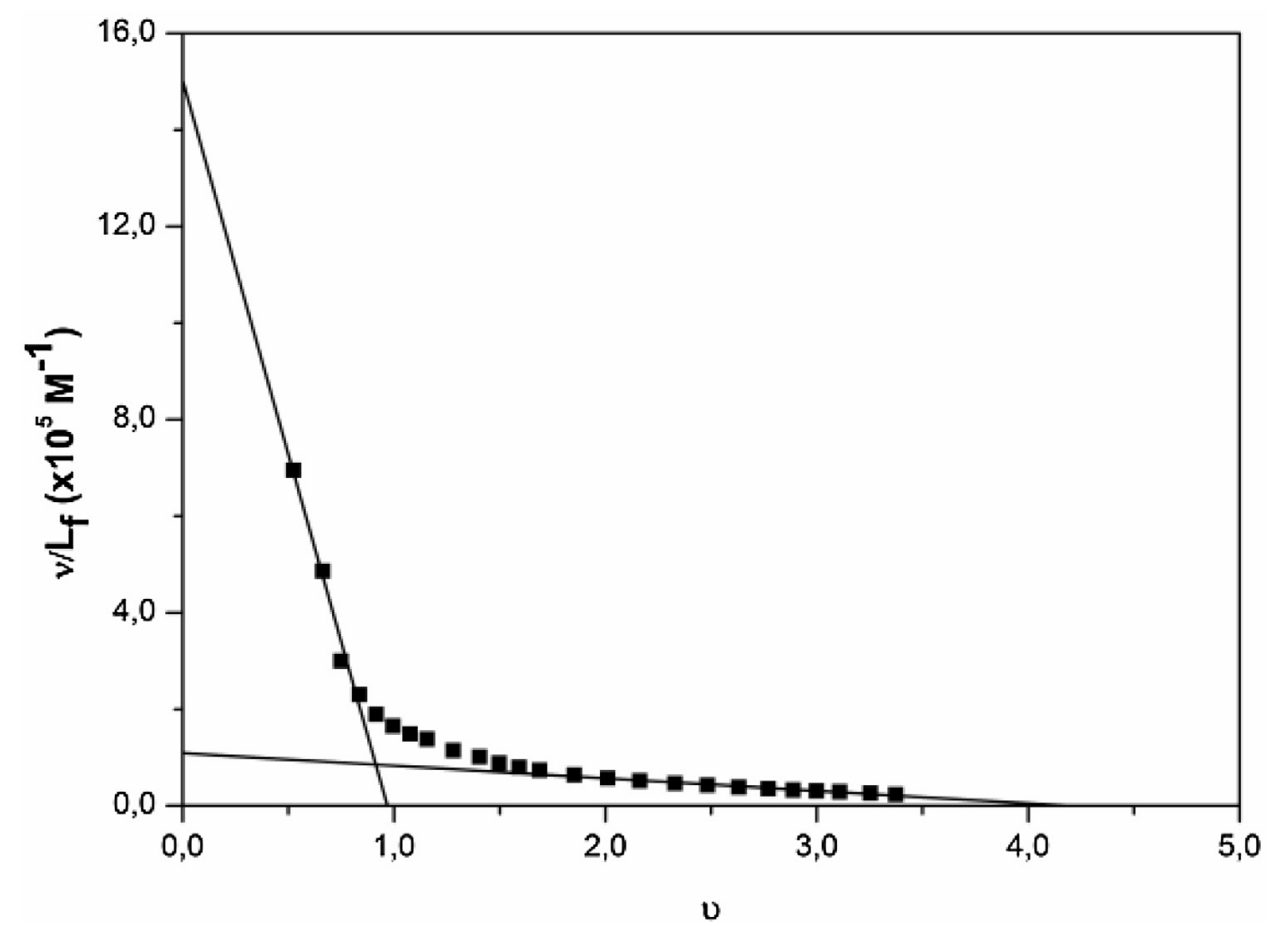

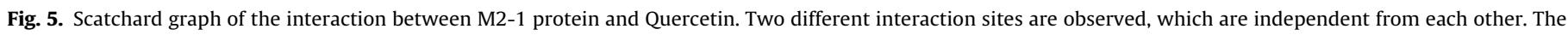
straight line represents the linear adjustments.

the van't Hoff analysis that the strong site has a negative enthalpy change $(-3.6 \mathrm{Kcal} / \mathrm{mol}$, exothermic reaction), whereas the weak site has a positive enthalpy change $(4.4 \mathrm{Kcal} / \mathrm{mol}$, endothermic reaction). Table 2 and Fig. 7 show the thermodynamic parameters obtained from the fluorimetric titration experiments, as well as the variations of these parameters in the temperature range explored. The $\Delta \mathrm{H}$ and $\Delta \mathrm{S}$ values suggest that there are contributions of electrostatic $(\Delta \mathrm{H}<0$ and $\Delta \mathrm{S}>0)$ and hydrophobic $(\Delta \mathrm{H}>0$ and $\Delta \mathrm{S}>0)$ 


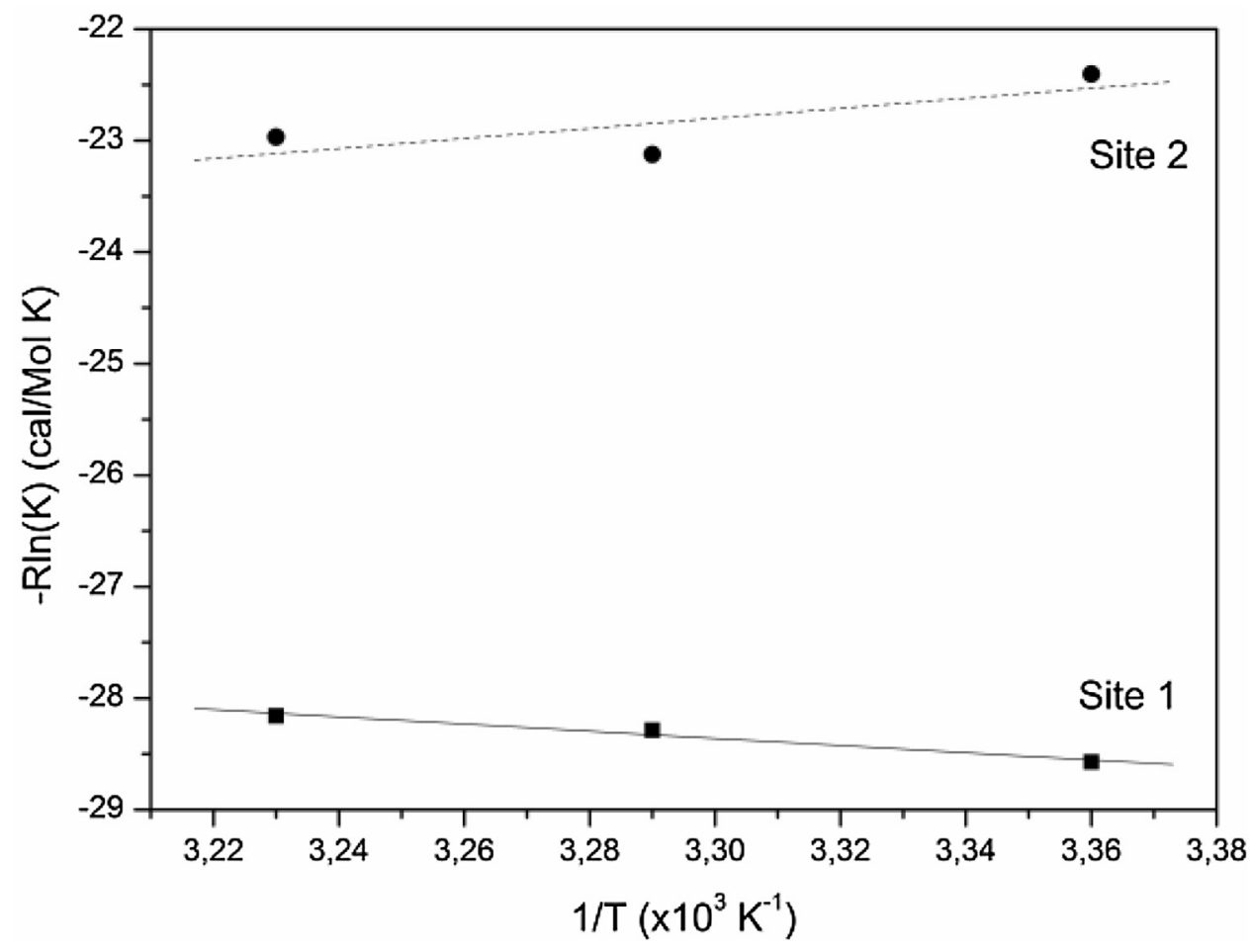

Fig. 6. Van't Hoff plot related to M2-1 protein interaction with Quercetin.

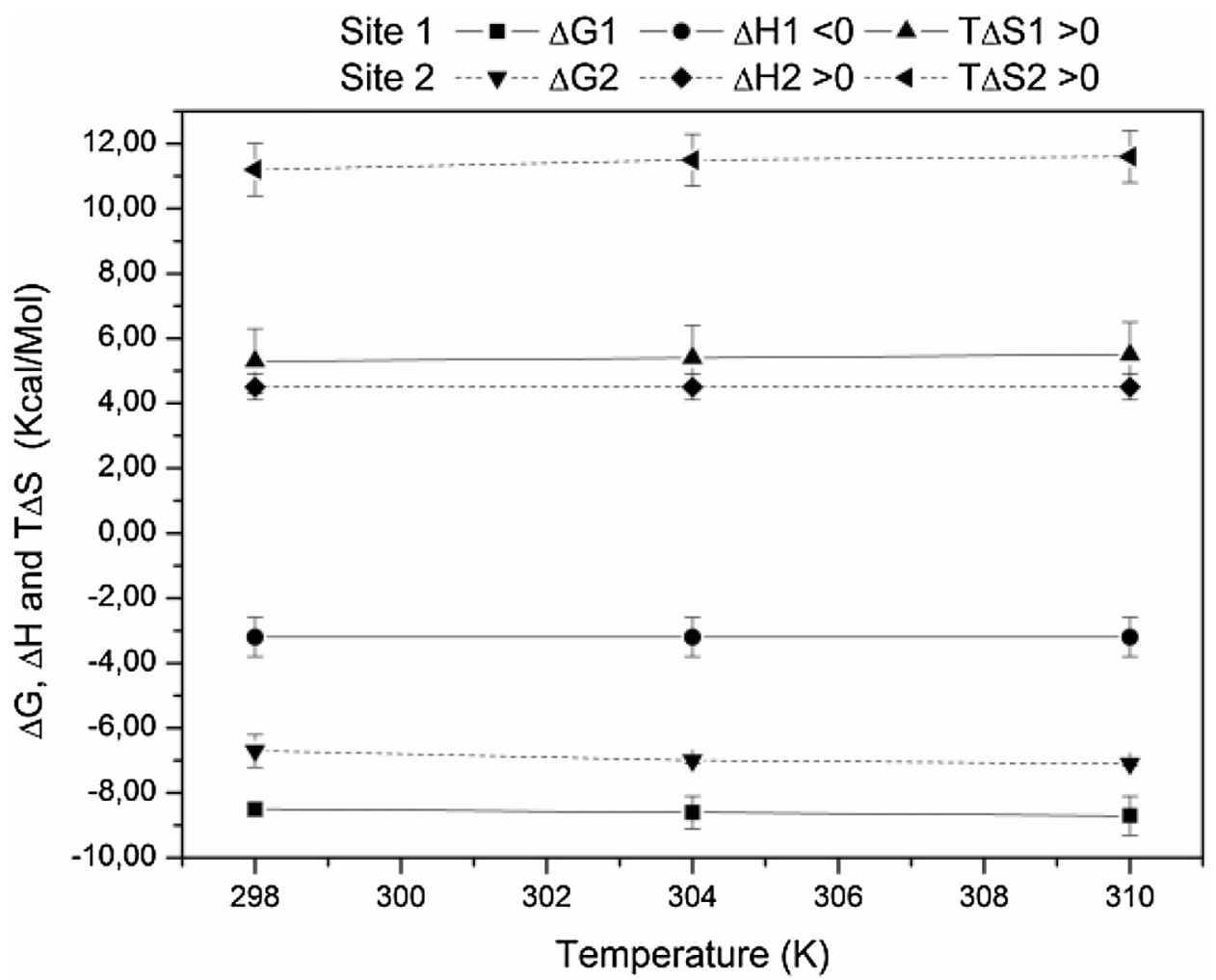

Fig. 7. Temperature-dependence of $\Delta \mathrm{G}, \Delta \mathrm{H}$ and $\mathrm{T} \Delta \mathrm{S}$ for the interaction of M2-1 protein with Quercetin in sites 1 and 2.

Table 1

Constant association of site 1 (K1) and site 2 (K2) in three different temperatures.

\begin{tabular}{llll}
\hline Constant & $298 \mathrm{~K}$ & $304 \mathrm{~K}$ & $310 \mathrm{~K}$ \\
\hline $\mathrm{K} 1\left(\times 10^{6} \mathrm{M}^{-1}\right)$ & $1.85 \pm 0.04$ & $1.60 \pm 0.10$ & $1.50 \pm 0.10$ \\
$\mathrm{~K} 2\left(\times 10^{5} \mathrm{M}^{-1}\right)$ & $0.82 \pm 0.06$ & $1.18 \pm 0.02$ & $1.09 \pm 0.01$ \\
\hline
\end{tabular}

interactions in the strong (site 1) and weak (site 2) sites, respectively, for the formation and stabilization of the M2-1/Quercetin complex.

As the N-terminus face of M2-1 is highly positive and the Cterminus face is also positive with four negative points [11], we can 

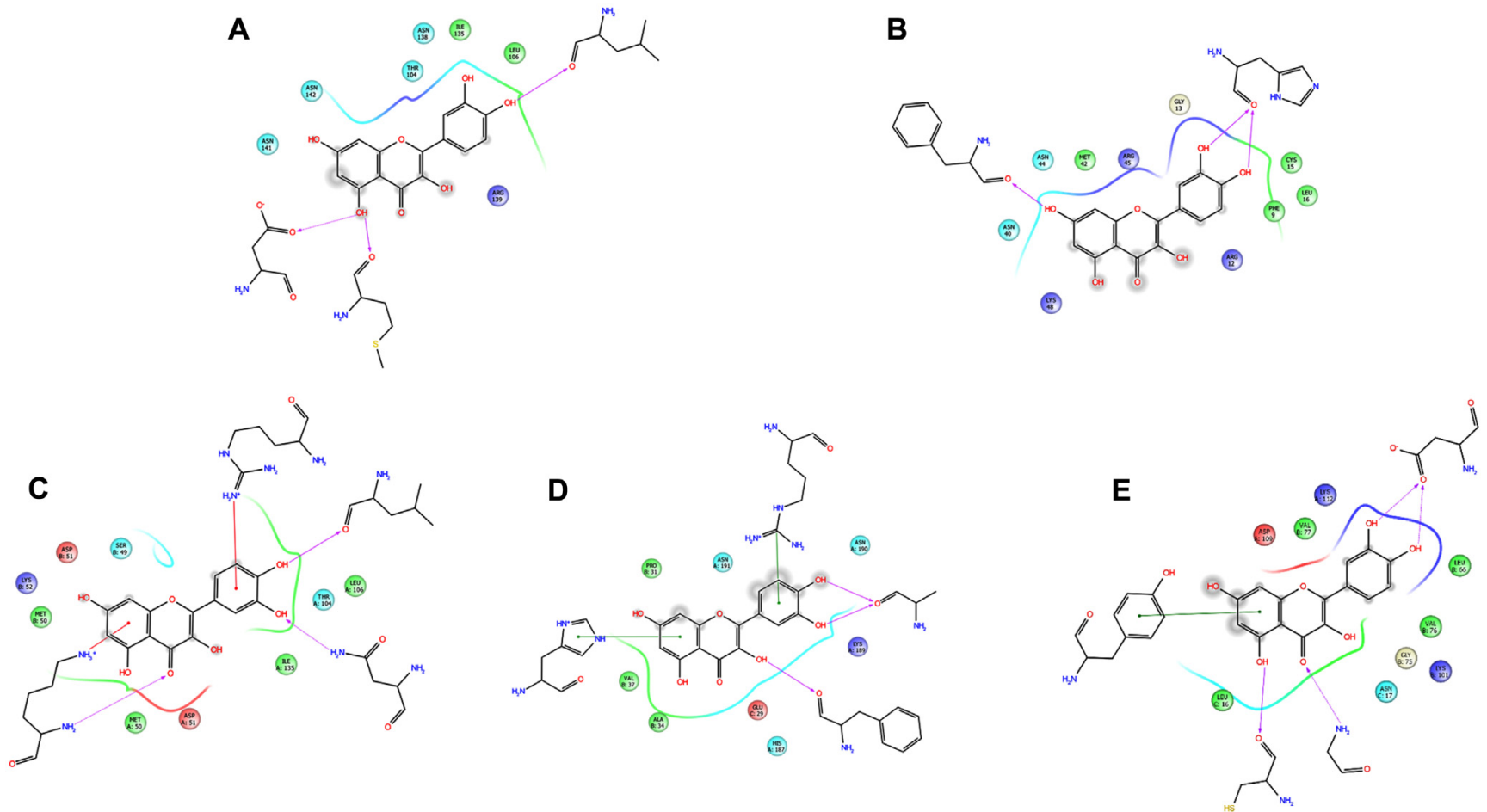

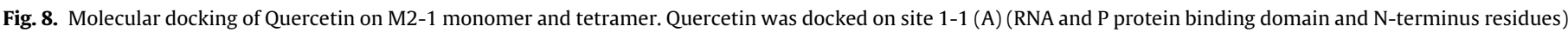

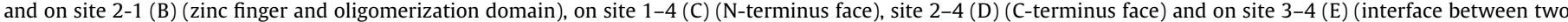

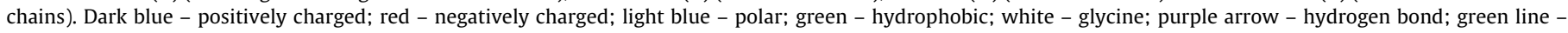

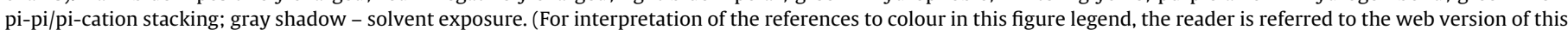
article.)

Table 2

$\Delta \mathrm{G}, \Delta \mathrm{H}$ and $\mathrm{T} \Delta \mathrm{S}$ values of the interaction of the M2-1 protein with Quercetin to the both binding sites.

\begin{tabular}{llll}
\hline $\mathrm{Kcal} / \mathrm{mol}$ & $298 \mathrm{~K}$ & $304 \mathrm{~K}$ & $310 \mathrm{~K}$ \\
\hline$\Delta \mathrm{G} 1$ & $-8.15 \pm 0.02$ & $-8.60 \pm 0.05$ & $-8.73 \pm 0.06$ \\
$\Delta \mathrm{G} 2$ & $-6.7 \pm 0.05$ & $-7.00 \pm 0.01$ & $-7.10 \pm 0.07$ \\
$\Delta \mathrm{H} 1$ & $-3.2 \pm 0.6$ & $-3.2 \pm 0.6$ & $-3.2 \pm 0.06$ \\
$\Delta \mathrm{H} 2$ & $4.4 \pm 0.4$ & $4.4 \pm 0.4$ & $4.4 \pm 0.4$ \\
$\mathrm{~T} \Delta \mathrm{S} 1$ & $5.3 \pm 0.9$ & $5.4 \pm 0.9$ & $5.5 \pm 0.9$ \\
$\mathrm{~T} \Delta \mathrm{S} 2$ & $11.1 \pm 0.8$ & $11.4 \pm 0.2$ & $11.5 \pm 0.1$ \\
\hline
\end{tabular}

$\Delta G 1=$ free energy variation on site $1, \Delta G 2=$ free energy variation on site $2, \Delta H 1=$ enthalpy variation on site $1, \Delta H 2=$ enthalpy variation on site 2 , $\mathrm{T} \Delta \mathrm{S} 1$ = entropy variation on site $1, \mathrm{~T} \Delta \mathrm{S} 2$ = entropy variation on site 2.

postulate that the partially negative regions of Quercetin (formed by the hydroxyl and ketone groups) could lead this molecule to interact at these two points. When these sites are full, the surface between the chains (which has neutral charge points), could accommodate the non-polar chain of Quercetin by hydrophobic interaction.

\subsection{Molecular docking}

The molecular docking study was performed on M2-1 monomer and tetramer $(\mathrm{PDB}$ code $=4 \mathrm{C} 3 \mathrm{~B})$. The monomer was divided in two regions (Fig. S4) to perform the molecular docking. Site 1-1 (site 1 of the monomer) is encompassed by a globular domain ( $\mathrm{P}$ protein and RNA biding domain) and protein C-terminus, and site 2-1 (site 2 of the monomer) encompasses the zinc finger and oligomerization domain. On site 1-1, Quercetin has a binding energy of $-6.41 \mathrm{kcal} / \mathrm{mol}$ and forms three hydrogen bonds (Met50, Asp51 and Leu103). The ligand interacts in a pocket between the oligomerization domain and the globular domain (Fig. 8A). On site 2-1, Quercetin has a binding energy of $-5.21 \mathrm{kcal} / \mathrm{mol}$ and forms three hydrogen bonds (His14 and Phe41). In this site, the ligand interacts with the zinc finger domain, close to the metal zinc (Fig. 8B).

As M2-1 tetramer is bigger than the grid box, the docking on M2-1 tetramer was performed in three points (Fig. S3) which encompass the whole molecule. The Quercetin ligand was docked on the central cavity of the N-terminus (site 1-4-site 1 of the tetramer) and C-terminus (site 2-4-site 2 of the tetramer) faces and on the interface between two chains (site 3-4-site 3 of the tetramer) (Face names taken from Tanner et al., 2014).

On site $1-4$, quercetin binding energy was $-7.36 \mathrm{kcal} / \mathrm{mol}$. The ligand interacted in a region between 2 chains (Fig. S4), making three hydrogen bonds (Lys52, Leu103 and Asn138) and two pication interactions (Lys52 and Arg139) (Fig. 8C). On site 2-4 (Fig. S4), the binding energy was $-5.24 \mathrm{kcal} / \mathrm{mol}$ and Quercetin formed three hydrogen bonds ( $\mathrm{Ph} 28$ and Ala188) and two pi-pi stacking (Arg3 and His33) (Fig. 8D). The molecule interacts with a region between the zinc finger domain and the unstructured C-terminus domain, close to the oligomerization domain. For site 3-4, binding energy was $-7.36 \mathrm{kcal} / \mathrm{mol}$ and four hydrogen bonds were observed (Cys15, Gly18 and Asp67) (Fig. 8E). The flavonol Quercetin interacts with a pocket between the P protein and RNA domain and the oligomerization domain, close to the metal zinc (Fig. S4).

By the docking results we can postulate that Quercetin interacts preferably with site 1-1 than with 2-1 of the monomer, close to $\alpha 2$ helix (where M2-1 binds to RNA) [49]. Additionally, this hypothesis can be reinforced by the fact that Quercetin has some similarity to adenine, which showed that residues Ser58-Lys177 have a high affinity for uracil and adenine [11].

The characteristics of the interaction with the site with strong binding association (site 1-4 and 2-4) and the one with weak binding association (site 3-4) correlates experimental data with molecular docking data. Sites 1-4 and 2-4, on docking, had more 
charged residues than site $3-4$, which had more hydrophobic residues.

\section{Conclusion}

In conclusion, M2-1 protein is mainly composed of alpha helix, with a melting temperature of about $328.6 \mathrm{~K}\left(\approx 55^{\circ} \mathrm{C}\right)$. From the fluorescence quenching, it was observed that Quercetin interacts in two sites, one with a strong association constant (site $1=\sim 1.5 \times 10^{6} \mathrm{M}^{-1}$ ) and another with a weak association constant ( site $2=1.1 \times 105 \mathrm{M}^{-1}$ ). Site 1 is occupied by 0.25 ligand/protein, or 1 ligand/tetramer, and site 2 is occupied by 1 ligand/protein, or 4 ligands/tetramer. Binding sites 1 and 2 are independent from each another. The thermodynamics analysis showed that the interaction of Quercetin at site 1 is by electrostatic interactions $(\Delta \mathrm{H}<0$ and $\Delta S>0)$ and at site 2 is by hydrophobic interactions $(\Delta H>0$ and $\Delta S>0)$.

The molecular docking of Quercetin in monomeric form shows that the interaction occurs in superficial pockets between the protein C-terminus and RNA and protein P interaction domain. This interaction is on a polar pocket stabilized by hydrogen bonds. However, docking with the tetrameric form occurs at two points, on the $\mathrm{N}$-terminus face close to the $\alpha 2$ helix and between chains at the interface between the oligomerization domains and the binding domains for RNA and P protein. In the first case, the interaction is on a more polar pocket stabilized by hydrogen bonds and pipi/pi-cation stacking and on the second case, Quercetin interacts with a more hydrophobic pocket stabilized by pi-pi stacking and hydrogen bonds. Therefore, Quercetin could interact with M2-1 in important domains for its activity and thus this flavonoid could avoid virus replication and budding.

\section{Acknowledgments}

This work was supported by Fundação de Amparo à Pesquisa do Estado de São Paulo (FAPESP - Processo 13/24355-2). We thank Prof. Dr. Altair Benedito Moreira for the access to the fluorescence spectrometer (Processo FAPESP: 2014/17511-0), Dr. Nathalia Baptista Dias and Prof. Dr. Mário Sergio Palma for having performed the protein sequencing, Prof. Dr. Marcio Francisco Colombo for the access to the Äkta purifier and $\operatorname{Dr}^{a} \stackrel{a}{-}$ Tereza Pereira de Souza for reviewing this paper.

\section{Appendix A. Supplementary data}

Supplementary data associated with this article can be found, in the online version, at http://dx.doi.org/10.1016/j.ijbiomac.2016. 11.033.

\section{References}

[1] A.T. Borchers, C. Chang, M.E. Gershwin, L.J. Gershwin, Respiratory syncytial virus-a comprehensive review, Clin. Rev. Allergy Immunol. 45 (2013) 331-379.

[2] P.L. Collins, J.A. Melero, Progress in understanding and controlling respiratory syncytial virus: still crazy after all these years, Virus Res. 162 (2011) 80-99.

[3] H. Nair, D.J. Nokes, B.D. Gessner, M. Dherani, S.A. Madhi, R.J. Singleton, K.L. O'Brien, A. Roca, P.F. Wright, N. Bruce, A. Chandran, E. Theodoratou, A. Sutanto, E.R. Sedyaningsih, M. Ngama, P.K. Munywoki, C. Kartasasmita, E.A Simões, I. Rudan, M.W. Weber, H. Campbell, Global burden of acute lower respiratory infections due to respiratory syncytial virus in young children: a systematic review and meta-analysis, Lancet 375 (2010) 1545-1555.

[4] K.A. Baker, M.E. Ryan, RSV infection in infants and young children. What's new in diagnosis, treatment, and prevention? Postgrad. Med. 106 (97-9) (1999) 103-104, 7-8 passim.

[5] F.W. Henderson, A.M. Collier, W.A. Clyde Jr., F.W. Denny, Respiratory syncytial virus infections reinfections and immunity. A prospective, longitudinal study in young children, N. Engl. J. Med. 300 (1979) 530-534.

[6] N.S.O. Santos, M.T.V.R. Romanos, M.D. Wigg, Introdução à Virologia Humana, 2ª edição, Guanabara Koogan, Rio de Janeiro, 2008.
[7] P.L. Collins, M.G. Hill, H. Grosfeld, Transcription elongation factor of respiratory syncytial virus: a nonsegmented negative-strand RNA virus, PNAS 93 (1996) 81-85

[8] R. Ghildyal, D. Li, I. Peroulis, B. Shields, P.G. Bardin, M.N. Teng, P.L. Collins, J. Meanger, J. Mills. Interaction between the respiratory syncytial virus G glycoprotein cytoplasmic domain and the matrix protein, J. Gen. Virol. 86 (2005) 1879-1884

[9] D. Li, D.A. Jans, P.G. Bardin, J. Meanger, J. Mills, R. Ghildyal, Association of respiratory syncytial virus $M$ protein with viral nucleocapsids is mediated by the M2-1 protein, J. Virol. 82 (2008) 8863-8870.

[10] R. Ghildyal, J. Mills, M. Murray, N. Vardaxis, J. Meanger, Respiratory syncytial virus matrix protein associates with nucleocapsids in infected cells, J. Gen. Virol. 83 (2002) 753-757.

[11] S.J. Tanner, A. Ariza, C.A. Richard, H.F. Kyle, R.L. Dods, M.L. Blondot, W. Wu, J. Trincão, C.H. Trinh, J.A. Hiscox, M.W. Carroll, N.J. Silman, J.F. Eléouët, T.A. Edwards, J.N. Barr, Crystal structure of the essential transcription antiterminator M2-1 protein of human respiratory syncytial virus and implications of its phosphorylation, Proc. Natl. Acad. Sci. U. S. A. 111 (2014) $1580-1585$

[12] V. Dubosclard, M.L. Blondot, J.F. Eléouët, F. Bontems, C. Sizun, 1H, 13C, and $15 \mathrm{~N}$ resonance assignment of the central domain of hRSV transcription antitermination factor M2-1, Biomol. NMR Assign 5 (2011) 237-239.

[13] T.L. Tran, N. Castagné, V. Dubosclard, S. Noinville, E. Koch, M. Moudjou, C. Henry, J. Bernard, R.P. Yeo, J.F. Eléouët, The respiratory syncytial virus M2-1 protein forms tetramers and interacts with RNA and $\mathrm{P}$ in a competitive manner, J. Virol. 83 (2009) 6363-6374.

[14] R.W. Hardy, G.W. Wertz, The Cys(3)-His(1) motif of the respiratory syncytial virus M2-1 protein is essential for protein function, J. Virol. 74 (2000) 5880-5885.

[15] R.S. Tang, N. Nguyen, X. Cheng, H. Jin, Requirement of cysteines and length of the human respiratory syncytial virus M2-1 protein for protein function and virus viability, J. Virol. 75 (2001) 11328-11335.

[16] H. Zhou, X. Cheng, H. Jin, Identification of amino acids that are critical to the processivity function of respiratory syncytial virus M2-1 protein, J. Virol. 77 (2003) 5046-5053.

[17] A.J. Pelletier, J.M. Mansbach, C.A. Camargo Jr., Direct medical costs of bronchiolitis hospitalizations in the United States, Pediatrics 118 (2006) 2418-2423.

[18] H. Nair, W.A. Brooks, M. Katz, A. Roca, J.A. Berkley, S.A. Madhi, J.M. Simmerman, A. Gordon, M. Sato, S. Howie, A. Krishnan, M. Ope, K.A. Lindblade, P. Carosone-Link, M. Lucero, W. Ochieng, L. Kamimoto, E. Dueger, N. Bhat, S. Vong, E. Theodoratou, M. Chittaganpitch, O. Chimah, A. Balmaseda, P. Buchy, E. Harris, V. Evans, M. Katayose, B. Gaur, C. O'Callaghan-Gordo, D. Goswami, W. Arvelo, M. Venter, T. Briese, R. Tokarz, M.A. Widdowson, A.W. Mounts, R.F. Breiman, D.R. Feikin, K.P. Klugman, S.J. Olsen, B.D. Gessner, P.F. Wright, I. Rudan, S. Broor, E.A. Simões, H. Campbell, Global burden of respiratory infections due to sea- sonal influenza in young children: a systematic review and meta-analysis, Lancet 378 (2010) 1917-1930.

[19] R.W. Sidwell, D.L. Barnard, Respiratory syncytial virus infections: recent prospects for control, Antiviral Res. 71 (2006) 379-390.

[20] S. Crotty, R. Andino, Implications of high RNA virus mutation rates: lethal mutagenesis and the antiviral drug ribavirin, Microbes Infect. 4 (2002) 1301-1307.

[21] S. Crotty, C. Cameron, R. Andino, Ribavirin's antiviral mechanism of action: lethal mutagenesis, J. Mol. Med. 80 (2002) 86-95.

[22] C. Fenton, L.J. Scott, G.L. Plosker, Palivizumab: a review of its use as prophylaxis for serious respiratory syncytial virus infection, Paediatr. Drugs 6 (2004) 177-197

[23] H. Wu, D.S. Pfarr, Y. Tang, L.L. An, N.K. Patel, J.D. Watkins, W.D. Huse, P.A. Kiener, J.F. Young, Ultra-potent antibodies against respiratory syncytial virus: effects of binding kinetics and binding valence on viral neutralization, J. Mol. Biol. 350 (2005) 126-144.

[24] L.K. Pickering, C.J. Baker, D.W. Kimberlin, S.S. Long, American Academy of Pediatrics: Respiratory Syncytial Virus, 2009, pp. 560-568.

[25] M.S. Butler, Natural products to drugs: natural product derived compounds in clinical trials, Nat. Prod. Rep. 22 (2005) 162-195.

[26] A.L. Harvey, Natural products in drug discovery, Drug Discovery Today 13 (2008) 894-901

[27] C.M.O. Simões, E.P. Schenkel, G. Gosmann, Farmacognosia - Da Planta Ao Medicamento, 5 a ed., Editora da UFSC, Santa Catarina, 2004

[28] L.H. Cazarolli, L. Zanatta, E.H. Alberton, M.S. Figueiredo, P. Folador, R.G. Damazio, M.G. Pizzolatti, F.P. Silva, Flavonoids: prospective drug candidates, Med. Chem. 8 (2008) 1429-1440.

[29] H. Wiegand, C. Boesch-Saadatmandi, I. Regos, D. Treutter, S. Wolffram, G. Rimbach, Effects of quercetin and catechin on hepatic glutathione-s transferase (GST) NAD(P)H quinone oxidoreductase 1 (NQO1), and antioxidant enzyme activity levels in rats, Nutr. Cancer 61 (2009) 717-722.

[30] R. Binsack, B.J. Boersma, R.P. Patel, M. Kirk, C.R. White, V. Darley-Usmar, S. Barnes, F. Zhou, D.A. Parks, Enhanced antioxidant activity after chlorination of quercetin by hypochlorous acid, Alcohol. Clin. Exp. Res. 25 (2001) 434-443.

[31] A. Murakami, H. Ashida, J. Terao, Multitargeted cancer prevention by quercetin, Cancer Lett. 269 (2008) 315-325.

[32] C.P. Xavier, C.F. Lima, M. Rohde, C. Pereira-Wilson, Quercetin enhances 5-fluorouracil-induced apoptosis in MSI colorectal cancer cells through p53 modulation, Cancer Chemother. Pharmacol. 68 (2011) 1449-1457. 
[33] F. Dajas, Life or death: neuroprotective and anticancer effects of quercetin, J. Ethnopharmacol. 143 (2012) 383-396.

[34] E.A. Murphy, J.M. Davis, J.L. McClellan, M.D. Carmichael, Quercetin's effects on intestinal polyp multiplicity and macrophage number in the $\mathrm{Apc}(\mathrm{Min} /+)$ mouse, Nutr. Cancer 63 (2011) 421-426.

[35] L.L. Wu, X.B. Yang, Z.M. Huang, H.Z. Liu, G.X. Wu, In vivo and in vitro antiviral activity of hyperoside extracted from Abelmoschus manihot (L) medik, Acta Pharmacol. Sinica 28 (2007) 404-409.

[36] S. Pisonero-Vaquero, M.V. Garcia-Mediavilla, F. Jorquera, P.L. Majano, M. Benet, R. Jover, J. Gonzalez-Gallego, S. Sanchez-Campos, Modulation of PI3K-LXRalpha-dependent lipogenesis mediated by oxidative/nitrosative stress contributes to inhibition of HCV replication by quercetin, Laboratory Investigation; a Journal of Technical Methods and Pathology 94 (2014) 262-274.

[37] Y.B. Yu, H. Miyashiro, N. Nakamura, M. Hattori, J.C. Park, Effects of triterpenoids and flavonoids isolated from Alnus firma on HIV-1 viral enzymes, Arch. Pharm. Res. 30 (2007) 820-826.

[38] G. Spedding, A. Ratty, E. Middleton Jr., Inhibition of reverse transcriptases by flavonoids, Antiviral Res. 12 (1989) 99-110.

[39] A. Ahmed-Belkacem, J.F. Guichou, R. Brillet, N. Ahnou, E. Hernandez, C. Pallier J.M. Pawlotsky, Inhibition of RNA binding to hepatitis C virus RNA-dependent RNA polymerase: a new mechanism for antiviral intervention, Nucleic Acids Res. 42 (2014) 9399-9409.

[40] T.N. Kaul, E. Middleton Jr., P.L. Ogra, Antiviral effect of flavonoids on human viruses, J Med Virol. 15 (1985) 71-79.

[41] L.C. Gillet, P. Navarro, S. Tate, H. Röst, N. Selevsek, L. Reiter, R. Bonner, R. Aebersold, Targeted data extraction of the MS/MS spectra generated by data-independent acquisition: a new concept for consistent and accurate proteome analysis, Mol. Cell. Proteomics 11 (2012) 0111.016717-0111.016717).

[42] N. Sreerama, R.W. Woody, Estimation of protein secondary structure from circular dichroism spectra: comparison of CONTIN, SELCON, and CDSSTR methods with an expanded reference set, Anal. Biochem. 15 (2000) 252-260.

[43] The Merck Index, 11th, Entry\# 8044.

[44] E. Gasteiger, C. Hoogland, A. Gattiker, S. Duvaud, M.R. Wilkins, R.D. Appel, A Bairoch, Protein identification and analysis tools on the ExPASy server, in: M. John Walker (Ed.), The Proteomics Protocols Handbook, Humana Press, 2005, pp. 571-607.

[45] R. Morris, W. Huey, M.F. Lindstrom, R.K. Sanner, D.S. Belew, Autodock4 and AutoDockTools4: automated docking with selective receptor flexiblity, J. Comput. Chem. 16 (2009) 2785-2791.

[46] M.F. Sanner, Python: a programming language for software integration and development, J. Mol. Graphics Mod. 17 (1999) 57-61.

[47 E.F. Pettersen, T.D. Goddard, C.C. Huang, G.S. Couch, D.M. Greenblatt, E.C. Meng, T.E. Ferrin, UCSF Chimera - a visualization system for exploratory research and analysis, J. Comput. Chem. 25 (2004) 1605-1612.

[48] Maestro, Maestro, Version 10.4, Schrödinger, LLC, New York, NY, 2015.

[49] M.L. Blondot, V. Dubosclard, J. Fix, S. Lassoued, M. Aumont-Nicaise, F. Bontems, C. Sizun, Structure and functional analysis of the RNA- and viral phosphoprotein-binding domain of respiratory syncytial virus M2-1 protein, PLoS Pathog. 8 (2012) 1002734 